\section{Evaluation of the Quality of Life of Anesthesiologists in the City of Recife}

Roberto Alves Calumbi, M.D., Jane Auxiliadora Amorim, TSA, M.D., Carmem Maria Caricio Maciel, TSA, M.D., Otávio Damázio Filho, TSA, M.D., Aldemir José Ferreira Teles, M.D.

\section{INTRODUCTION}

In the last several years, concerns on the quality of life aimed at an integral wellbeing have been increasing ${ }^{1}$. The expression "quality of life" is present in many studies, with work-, health-, and holistic vision-related approaches to life, with specific concepts in each area. Quality of life is defined by the Quality of Life Group of the World Health Organization as "the individual perception of one's position in life in the context of the cultural and system of values one lives in and in relation with his/her objectives, expectations, standards, and concerns"2. This encompasses physical health, psychological status, level of independence, social relationships, personal beliefs, and the relationship with the main characteristics of the environment of an individual. In this definition, the subjective nature of the evaluation is emphasized, with positive and negative dimensions, which is intertwined with the cultural, social, and environmental contexts, emphasizing the perception of the individual on his/her quality of life ${ }^{3}$. Anesthesiology is considered a subspecialty associated with elevated levels of stress, which can result in negative consequences for those who practice it ${ }^{4-8}$. Despite the importance of the subject, very few studies in the literature have evaluated the quality of life of those professionals. In the present study, the quality of life of anesthesiologists who work in the greater Recife area, correlating the profile of quality of life with the degree of satisfaction with health, number of work days and weekly shifts, gender, and age group.

\section{METHODS}

The population of this descriptive, exploratory, transversal study was composed of anesthesiologists associated with the Cooperativa dos Médicos Anestesiologistas de Pernambuco (COOPANEST-PE) who practice in greater Recife. The dissemination of this study was promoted during the local scientific workshop, promoted by the Pernambuco Anesthesia Society (SAEPE, from the Portuguese), and at COOPANEST-PE headquarters. Data were collected over a three-month period. All 351 anesthesiologists associated with those institutions were invited to participate in the study. Participants answered a questionnaire on personal data (age, gender, marital status, medical school, and number of work days and shifts per week); however, they were not required to identify themselves. The short form of the questionnaire developed by the Quality of Life Group of the World Health Organization, World Health Organization Quality of Life (WHOQOL) - WHOQOL-BREF - composed of 26 questions, was used to evaluate quality of life. It is composed by two general questions on quality of life and degree of satisfaction with one's health, and 24 basic questions on the physical and psychological domains, social relationships, and environment, that allow the subjective evaluation of the degree of satisfaction of the individual with his/her life, ability to work, physical appearance, access to information, leisure, sleep, financial status, home, sex life, working conditions and health services, social relationships in general, and safety at work and home, among others.

The SPSS 11.0 (Statistical Package for the Social Science) was used to analyze the data. Descriptive data was expressed as percentages, and means and standard deviation. Transformation of the parameters and statistical calculations followed the guidelines of the World Health Organization Quality of Life Group ${ }^{3}$. Spearman's correlation and Student $t$ test and ANOVA, as well as Scheffé test for variances were used, considering a $p<0.05$ significant.

\section{RESULTS}

One hundred and ten (31.3\%) anesthesiologists answered the questionnaire. Female anesthesiologists (69\%), married $(62 \%)$, in the $43.2 \pm 11.1$ years, with the Title of Anesthesiology Specialist (71\%) predominated (Table I). As for the number of working days, $58 \%$ worked six to seven days a week. Mean weekly work shifts was $15.5 \pm 4.1 ; 12(18 \%)$ anesthesiologists

Table I - General Characteristics of the Study Population

\begin{tabular}{lrr}
\hline Parameter & $\mathrm{n}$ & $\%$ \\
\hline Gender & 34 & 31 \\
Male & 76 & 69 \\
Female & & \\
Age group (years) & 40 & 36 \\
24 to 39 & 61 & 56 \\
40 to 59 & 9 & 8 \\
60 or more & & \\
Marital Status & 29 & 26 \\
Single & 68 & 62 \\
Married & 11 & 10 \\
Divorced & 2 & 2 \\
$\quad$ Widow & & \\
Degree & 10 & 9 \\
Adjunct Member & 78 & 71 \\
Title of Anesthesiology Specialist & 18 & 16 \\
Superior Title of Anesthesiology & 3 & 3 \\
Incomplete Master's Degree & 1 & 1 \\
Master's Degree & & \\
\hline
\end{tabular}

$\mathrm{n}=$ number of anesthesiologists. 
Table II - Self-Evaluation of Anesthesiologists Regarding Quality of Life and Degree of Satisfaction with their Health

\begin{tabular}{lrr}
\hline Parameter & $\mathrm{n}$ & $\%$ \\
\hline Self-evaluation on quality of life & & \\
$\quad$ Very poor & 1 & 0.9 \\
Poor & 17 & 15.5 \\
Neither poor nor good & 31 & 28.2 \\
Good & 51 & 46.4 \\
Very good & 10 & 9.1 \\
Degree of satisfaction with health & & \\
Extremely displeased & 2 & 1.8 \\
Displeased & 23 & 20.9 \\
Neither pleased nor displeased & 18 & 16.4 \\
Pleased & 53 & 48.2 \\
Extremely pleased & 14 & 12.7 \\
\hline
\end{tabular}

$\mathrm{n}=$ number of anesthesiologists

Table III - Quality of Life Scores vs. Number of work Shifts

\begin{tabular}{lc}
\hline Number of work shifts & Score* $^{*}$ \\
\hline Up to $10(n=20)$ & $4.0 \pm 0.85$ \\
11 to $18(n=72)$ & $3.43 \pm 0.76$ \\
19 to $21(n=18)$ & $3.05 \pm 1.16$ \\
$p$ & $0.03^{1}$ \\
\hline
\end{tabular}

* Results expressed as Mean \pm Standard deviation;

$p^{1}-\mathrm{F}$ test (ANOVA)

$n=$ number of anesthesiologists.

Table IV - Mean and Standard Deviation of the Scores of Females and Males

\begin{tabular}{lccc}
\hline Dominion & $\begin{array}{c}\text { Females } \\
(\mathrm{n}=76)\end{array}$ & $\begin{array}{c}\text { Males } \\
(\mathrm{n}=34)\end{array}$ & $p$ \\
\hline Physical & $68.80 \pm 14.49$ & $74.16 \pm 14.37$ & $p^{1}=0.075$ \\
Psychological & $66.23 \pm 13.48$ & $72.67 \pm 11.10$ & $p^{1}=0.016^{*}$ \\
Social relationships & $63.71 \pm 19.89$ & $73.04 \pm 16.16$ & $p^{1}=0.018^{*}$ \\
Environment & $61.35 \pm 11.39$ & $65.72 \pm 14.42$ & $p^{2}=0.090$ \\
General & $65.02 \pm 12.50$ & $71.40 \pm 12.04$ & $p^{1}=0.014^{*}$ \\
\hline
\end{tabular}

$\mathrm{n}=$ number of anesthesiologists;

* = statistically significant difference;

$p^{1}=$ Student $t$ test with equal variances.

$p^{2}=$ Student $t$ test with unequal variances. worked up to 10 weekly shifts, $72(67 \%) 11$ to 18 shifts, and $18(15 \%) 19$ to 21 shifts (Table III). Sixteen anesthesiologists worked 21 shifts per week, i.e., mornings, afternoons, and nights of every week day.

Self-evaluation of their quality of life revealed that $55.5 \%$ considered it good or very good; $28.2 \%$ neither good nor poor; and $16.4 \%$, poor or very poor. Regarding the degree of satisfaction with their health, $61 \%$ were pleased of very pleased; $16.4 \%$ neither pleased nor displeased; and $22.7 \%$ displeased or extremely displeased (Table II). Analysis of the coefficient of correlation between self-evaluation of the quality of life and degree of satisfaction with their health showed a significant relationship between those parameters $(r=0.525 ; p=0.01)$. Mean perception of quality of life scores was significantly higher among anesthesiologists who work less shifts per week ( $p=0.03$; Table III).

Women had significantly lower scores than men in the subjective evaluation of quality of life and in the psychological and social relationships domains (Table IV). The age group of 60 years or more had the best scores in all domains, but without statistically significant differences (Table V). Anesthesiologists who work three to five days a week had better scores in all domains when compared to those who work six to seven days a week, but this difference was not statistically significant (Table $\mathrm{VI}$ ). Among the domains evaluated, the environment had lower scores.

Table VI - Mean and Standard Deviation of the Scores According to the Number of Work Days

\begin{tabular}{lllc}
\hline & \multicolumn{3}{c}{ Work days } \\
\cline { 2 - 4 } Dominion & 3 to $5(\mathrm{n}=46)$ & 6 to $7(\mathrm{n}=64)$ & $p$ \\
\hline Physical & $71.27 \pm 13.57$ & $69.87 \pm 15.38$ & $p^{1}=0.620$ \\
Psychological & $69.29 \pm 12.86$ & $67.45 \pm 13.30$ & $p^{1}=0.468$ \\
Social relationships & $67.21 \pm 20.52$ & $66.15 \pm 18.42$ & $p^{1}=0.776$ \\
Environment & $64.61 \pm 11.20$ & $61.33 \pm 13.28$ & $p^{1}=0.176$ \\
General & $68.10 \pm 12.32$ & $66.20 \pm 12.93$ & $p^{1}=0.440$ \\
\hline
\end{tabular}

$\mathrm{n}=$ number of anesthesiologists;

$p^{1}=$ Student $t$ test with equal variances.

Table V - Mean and Standard Deviation of Scores per Age Group

\begin{tabular}{lcccc}
\hline & \multicolumn{4}{c}{ Age group (years) } \\
\cline { 2 - 5 } Dominion & 24 to $39(\mathrm{n}=40)$ & 40 to $59(\mathrm{n}=61)$ & 60 or more $(\mathrm{n}=9)$ & $p$ \\
\hline Physical & $69.29 \pm 15.26$ & $70.37 \pm 14.87$ & $76.19 \pm 8.18$ & $p^{1}=0.443$ \\
Psychological & $66.88 \pm 12.48$ & $68.37 \pm 13.51$ & $73.15 \pm 13.03$ & $p^{1}=0.430$ \\
Social relationships & $68.96 \pm 19.97$ & $64.48 \pm 18.69$ & $70.37 \pm 20.03$ & $p^{1}=0.434$ \\
Environment & $61.80 \pm 14.16$ & $62.35 \pm 10.97$ & $69.10 \pm 14.10$ & $p^{1}=0.273$ \\
General & $66.73 \pm 13.97$ & $66.39 \pm 12.08$ & $72.20 \pm 10.09$ & $p^{1}=0.436$ \\
\hline
\end{tabular}

$\mathrm{n}=$ number of anesthesiologists; $p^{1}=\mathrm{F}$ test (ANOVA). 


\section{DISCUSSION}

In the present study, $31.3 \%$ of anesthesiologists answered the questionnaire, a percentage that can be considered satisfactory for studies of this nature ${ }^{9}$. Similar adhesion (39.24\%) was obtained by a study that evaluated the practice of anesthesia among 739 anesthesiologists associated with the Sociedade de Anestesiologia do Rio Grande do Sul ${ }^{10}$. A metanalysis that evaluated the prevalence of burnout syndrome in health care professionals caring for oncology patients had an adhesion of approximately $20 \%$ in studies in English, Spanish, and Portuguese languages ${ }^{11}$.

Subjective analysis of the quality of life revealed an elevated percentage of anesthesiologists (44.6\%) with a negative or undefined perception of their quality of life. The degree of satisfaction with their health $(r=0.525 ; p=0.01)$ and long working hours (Table III) had a significant influence in the present study, since $67 \%$ of the anesthesiologists work between 11 and 18 shifts a week, and $15 \%$ up to 21 shifts a week, with little or no time left for rest and leisure. Among Uruguayan physicians, a study that used the WHOQOL-BREF also reported low quality of life scores and, among the contributing factors, long and excessive working hours ${ }^{12}$. The influence of health in the quality of life was expected since it has been observed in other studies ${ }^{12,13}$.

Long working hours result in several clinical manifestations, such as: fatigue; loss of energy; sleep and mood disorders; reduction in the ability to work, learn, think, and in memory; and difficulty in interpersonal relationships, among others ${ }^{8}$. A study with anesthesiology residents demonstrated that the 24- or 30-hour working shifts decreases sleep latency to less than five minutes, which is considered pathologic, reflecting fatigue and the need to rest after a long work shift ${ }^{14}$. Sleep deprivation alters, significantly, the clinical activity of physicians. Mistakes made by anesthesiologists can have catastrophic consequences if not corrected on time. Human factors like sleep deprivation, fatigue, and stress can increase the potential of human mistake and hinder effective recovery of the professional ${ }^{15}$.

The practice of Anesthesiology is tiresome and stressful. Vigilance and constant alertness, allowing prompt reaction in critical situations, are the most important characteristics of the life of anesthesiologists. The cognitive demands of patient care during the anesthetic-surgical procedure require fast access to and evaluation of information, and development and implementation of measures to maintain the patient in adequate clinical conditions. It involves the daily contact with the suffering of other people, demands constant medical updates and manual abilities, responsibility, and a good relationship with patients and the multi-professional team. In many situations, the stress associated with long working hours leads to dissatisfaction, which affects directly the quality of life and health of anesthesiologists, as observed in the present study.

A recent study undertaken by the Conselho Federal de Medicina demonstrated that $44 \%$ of Brazilian physicians have depression or anxiety, and $57 \%$ have signs of fatigue and discouragement with the profession. Besides, one in every five physicians has cardiovascular disease, and $71.8 \%$ suffer from some gastrointestinal disorder. When compared to managers, physicians have higher levels of stress hormones; and when compared to dentists and lawyers, physicians have a higher rate of myocardial infarction and early death ${ }^{16}$. A study that analyzed personality traits and attitudes of 231 anesthesiologists concluded that, in general, they are reserved, smart, objective, serious, conscious, self-confident, and tense when compared to physicians of other subspecialties $^{8}$. A study that evaluated blood pressure levels during the anesthetic procedure showed a significant increase in blood pressure ${ }^{17}$.

Prolonged and excessive working hours can lead to that stage of exhaustion known as Burnout Syndrome, which is characterized by emotional exhaustion, depersonalization, and compromised personal realization ${ }^{18}$. In the emotional exhaustion domain, the individual feels drained, with a feeling that it is not possible to recuperate his/her energy. He/she becomes irritated, bitter, not generous, pessimist, and less capable. In depersonalization, the person shows emotional withdrawing and indifference to the suffering of others, which, in the case of physicians, means treating patients as objects. In the professional realization domain, the individual feels impotent, frustrated, unhappy, and has low self-esteem. In a review of the literature ${ }^{4-7}$, the prevalence of burnout syndrome symptoms in anesthesiologists showed the following percentage variations: $17.0 \%$ to $40.4 \%$ of emotional exhaustion; $10.0 \%$ to $31.7 \%$, depersonalization; and $12.3 \%$ to $41.4 \%$, compromised personal realization. The chronicity of those symptoms can lead to dramatic problems, such as chemical dependency and suicidal attitudes, which are very prevalent in our subspecialty ${ }^{19,20}$.

In the city of Recife, the majority of anesthesiologists are females, who present significantly lower scores than men in the general evaluation of quality of life and in the psychological and social relationships domains (Table IV). Those results are related, among other factors mentioned, to the accumulation of tasks of modern women, since those domains evaluate negative feelings, self-esteem, body image and appearance, spirituality, personal relationships, social life, and sex life. A study on occupational stress and quality of life of Magistrates of Labor Courts had similar results. The quality of life of women was lower than that of men, and social, affective, professional, and health domains were more affected. Overwork and interference with family life were the most common stressors ${ }^{21}$. A study comparing the prevalence of burnout syndrome in teachers also demonstrated a greater prevalence in women (84.1\% vs. $77.2 \%$ in men). Those authors also observed a negative influence of psychological and social factors in females ${ }^{22}$. In this context, it is important that women carefully ponder their position in life regarding their objectives, expectations, values, standards, and worries, and develop measures to minimize the excessive workload and stress in their daily lives. A significant difference was not observed in the quality of life among the different age groups (Table V). As for specialization, the high 
percentage of specialists can be explained by the fact that Recife has three Centros de Ensino e Treinamento accredited by the Sociedade Brasileira de Anestesiologia.

Among the four domains evaluated, the environment had the lower scores. As an integral part of the surgical team responsible for operating and recovery rooms, anesthesiologists face high work-related risks due to exogenous and endogenous factors. Among exogenous factors with negative impact on health, environmental contamination caused by inhalation of anesthetics and disinfectants used in the operating room, exposure to radiation, and contamination by infectious agents should be mentioned. Endogenous factors are represented by psychosocial and emotional stimuli like those triggered by stress and anguish, which, usually, are the common denominator in the hospital environment due to the severity of the patients they care for ${ }^{8}$. Regarding safety and housing, the high violence and criminality rates recorded in Recife most likely influenced this result.

Some recommendations of the American Society of Anesthesiologists for Work Health of Surgical Teams ${ }^{23}$ are considered healthy ways of dealing with and, perhaps, can decrease the high level of daily stress of anesthesiologists, such as:

1. To develop self-esteem independent of being a physician so leisure time can be as fulfilling as work.

- To stay healthy by exercising and maintaining a healthy diet.

- To learn new abilities or develop intellectual interests other than medicine.

- To dedicate time for cultural activities (concerts, movies, museums).

- Befriend non-medical personnel.

- Join clubs.

- Do something creative: it can be relaxing and give voice to feelings that need to be expressed.

2. Spiritual development, reflect on the objective of our lives in this world.

3. Look for support from other friends, important people, mentors, and other role-models and therapists.

4. On the other hand, spend a few hours alone if your time is demanded too often.

5. Learn to express your feelings, maintain a diary or see a therapist.

- Do not accept undeserving abuse; you have to respect and accept yourself.

- Understand that you cannot please everyone.

- Learn to ask for what you need.

6. Remain flexible and open to changes and new experiences.

7. Maintain a good sense of humor.

- Do not take things too seriously.

- Admit that tomorrow will be a new day and that life goes on.

- Laughter can have some non-determined health benefits.

8. Happiness comes from the balance among work, leisure, and rest; remember that you deserve to be happy.
- The feeling of controlling one's own life can be important to achieve happiness.

9. Enjoy the time you are not working.

10. Develop a positive attitude.

- Optimists (defined as those who distort reality to create the illusion that they can achieve positive results) are happier and healthier.

11. Admit you can make mistakes.

12. Learn to say no: do not do too many things at the same time.

13. Develop better interpersonal aptitudes.

- Learn to deal efficiently with conflicts.

- Treat others with respect.

- Deal with your anger.

- Learn to solve problems instead of looking for the guilty party.

- Maintain the perspective.

- Listen.

- Do not give up.

- Use good sense of humor.

- Concentrate on the problem at hand, avoid personal critics.

- Avoid passive-aggressive behavior.

- Be honest.

- Do not hold a grudge.

- Try to solve your problems.

To conclude, in the present study, excess workload was a negative factor for the quality of life of anesthesiologists in the city of Recife; the quality of life of women was significantly lower to that of men. Those results indicate the need of reflection and actions that could have a positive influence on health and quality of life of those professionals. Besides individual actions, institutional support is fundamental for the practice of anesthesiology and, for positive changes, decisions should be based on scientific evidence.

\section{ACKNOWLEDGEMENTS}

We would like to acknowledge the support of the Cooperativa e Sociedade de Anestesiologia do Estado do Rio de Janeiro (2005-2006 Biennium) for their support in the dissemination and data collection.

\section{REFERÊNCIAS - REFERENCES}

1. Santos N. Antropotecnologia: a ergonomia dos sistemas de produção. Curitiba: Gênesis, 1997.

2. Fleck MPA, Louzada S, Xavier M et al. Aplicação da versão em português do instrumento abreviado de avaliação da qualidade de vida WHOQOL-bref. Rev Saúde Pública 2000;34:178-183.

3. Fleck MPA, Chachamoviche E, Trentini CM. Projeto WHOQOL-OLD: método e resultados de grupos focais no Brasil. Rev Saúde Pública 2003;37:793-799.

4. Fernandez Torres B, Roldan Pérez LM, Guerra Vélez A et al. Prevalencia del síndrome de Burnout en los anestesiólogos del Hospital Universitario Virgen Macarena de Sevilla. Rev Esp Anestesiol Reanim 2006;53:359-362. 
5. Palmer-Morales LY, Gómez-Vera A, Cabrera-Pivaral C et al. Prevalencia del síndrome de agotamiento profesional en médicos anestesiólogos de la ciudad de Mexicali. Gac Med Mex 2005;141:181-183.

6. Nyssen AS, Hansez I, Baele P et al. Occupational stress and burnout in anaesthesia. Br J Anaesth 2003;90:333-337.

7. Kluger MT, Townend K, Laidlaw T. Job satisfaction, stress and burnout in Australian specialist anaesthetists. Anaesthesia 2003;58:339-345.

8. Duval Neto GF. Stress e fadiga na segurança do ato anestésico: impacto no desempenho profissional. In: Cavalcanti IL, Cantinho FAF, Assad A. Medicina perioperatória. Rio de Janeiro: SAERJ 2006;965-971.

9. Thomas JR, Nelson JK. Métodos de pesquisa em educação física. Porto Alegre: Artmed, 2003.

10. Pilau MM, Bagatini A, Bondan LG et al. O anestesiologista no Rio Grande do Sul. Rev Bras Anestesiol 2000;50:309-316.

11. Trufelli DC, Bensi CG, Garcia JB et al. Burnout in cancer professionals: a systematic review and meta-analysis. Eur J Cancer Care 2008;17:524-531.

12. Schwartzmann L. La calidad de vida de los medicos: estudio de una muestra de medicos del Uruguay. Vertex 2007;18:103-110.

13. Mingote Adan JC, Moreno Jimenez B, Galvez Herrer M. Desgaste profesional y salud de los profesionales medicos: revision y propuestas de prevencion. Med Clin (Barc) 2004;123:265-270.

14. Mathias LAST, Coelho CMF, Vilela EP et al. O plantão noturno em anestesia reduz a latência ao sono. Rev Bras Anestesiol 2004; 54:694-699.

15. Weinger $\mathrm{MB}$, Englund $\mathrm{CE}$. Ergonomic and human factors affecting anesthetic vigilance and monitoring performance in the operating room environment. Anesthesiology 1990;73:995-1021.

16. Barbosa GA. A Saúde dos médicos no Brasil. Brasília, Conselho Federal de Medicina, 2007;220.

17. Aragão PW, Prazeres JO, Aragão VMF et al. Pressão arterial do anestesiologista durante 0 ato anestésico-cirúrgico no período matutino. Rev Bras Anestesiol 2002;52:591-600.

18. Alkema K. Linton JM. Davies R. A study of the relationship between self-care, compassion satisfaction, compassion fatigue, and burnout among hospice professionals.J Soc Work End Life Palliat Care 2008:4:101-119.

19. Duval Neto GF. Dependência química e os anestesiologistas. In: Cavalcanti IL, Cantinho FAF, Assad A. Medicina perioperatória. Rio de Janeiro: SAERJ, 2006;981-989.

20. Beaujouan L, Czernichow S, Pourriat JL et al. Prevalence et facteurs de risque de l'addiction aux substances psychoactives en milieu anesthesique: resultats de l'enquete nationale. Ann Fr Anesth Reanim 2005;24:471-479.

21. Lipp MEN, Tanganelli MS. Stress e qualidade de vida em magistrados da Justiça do Trabalho: diferenças entre homens e mulheres. Psicol Reflex Crit 2002;15:537-548.

22. Aldrete Rodríguez MG, Preciado Serrano ML, Franco Chávez SA et al. Factores psicosociales laborales y síndrome de burnout, diferencias entre hombres y mujeres docentes de secundaria, zona metropolitana de Guadalajara, México. Cienc Trab 2008;30:138-142.

23. Berry AJ, Arnold WP, Harter RL et al. Dependência química entre anestesiologistas. Tradução e publicação oficial da Comissão de Defesa Profissional da Sociedade Brasileira de Anestesiologia, 2006.

\section{RESUMEN}

Calumbi RA, Amorim JA, Maciel CMC, Damázio Filho O, Teles AFT Evaluación de la Calidad de Vida de los Anestesiólogos de la Ciudad de Recife.

JUSTIFICATIVA YOBJETIVOS: Lapráctica médica en Anestesiología es una actividad que desgasta y estresa. En este estudio, se evaluó la calidad de vida de los anestesiólogos que trabajan en la ciudad de Recife y se relacionó el perfil de calidad de vida, con el grado de satisfacción con relación a la salud, al número de días y a los turnos semanales trabajados, el sexo y la franja etaria.

MÉTODO: Se utilizó el cuestionario WHOQOL-BREF. Se aplicaron la correlación de Sperman y los tests t de Student, Anova y de variancia por el test de Scheffé, adoptándose los valores de $p<0,05$ como significativos.

RESULTADOS: El análisis subjetivo arrojó que un 44,6\% de los anestesiólogos tienen una percepción negativa o indefinida sobre su calidad de vida. Presentaron una influencia significativa en ese resultado, el grado de satisfacción con la salud $(r=0,525 ; p=0,01)$ $y$ el exceso de turnos semanales trabajados $(p=0,03)$. Las mujeres presentaron puntuaciones significativamente inferiores a la de los hombres en la evaluación subjetiva general de calidad de vida y en las áreas psicológica y de las relaciones sociales. No se encontró diferencia significativa en las diferentes franjas etarias. El área promedio ambiente presentó puntuaciones inferiores a la de los demás en todas las variables analizadas.

CONCLUSIONES: El exceso de trabajo fue un factor negativo en la calidad de vida de los anestesiólogos de la ciudad de Recife, y las mujeres presentaron una calidad de vida significativamente inferior a la de los hombres. Frente a esos resultados, entendimos que había una necesidad de reflexionar y de tomar actitudes que puedan influir positivamente en la salud y en la calidad de vida de esos profesionales. Para mejorar las actitudes individuales, es de fundamental importancia tener un apoyo institucional en la práctica anestésica y para los cambios positivos, las decisiones deben estar basadas en evidencias científicas. 